\title{
Academic Engagement: An Overview of Its Definitions, Dimensions, and Major Conceptualisations
}

\author{
Oqab Alrashidi ${ }^{1}$, Huy P. Phan ${ }^{1} \&$ Bing H. Ngu ${ }^{1}$ \\ ${ }^{1}$ School of Education, University of New England, Armidale, NSW, Australia \\ Correspondence: Oqab Alrashidi, School of Education, University of New England, Armidale, NSW, Australia. \\ Tel: 61-267-733-949. E-mail: oalrashi@myune.edu.au
}

Received: May 26, 2016

doi:10.5539/ies.v9n12p41
Accepted: June 30, $2016 \quad$ Online Published: November 24, 2016

URL: http://dx.doi.org/10.5539/ies.v9n12p41

\begin{abstract}
Engagement is a prominent theoretical orientation that has received great attention from educators and researchers. This article provides a literature overview of the engagement construct pertaining to its various definitions, dimensions, and major conceptualisations. In addition, the review sheds light on two major approaches to engagement in the current literature: one entails students' cognitive, behavioural, and emotional engagement (Fredricks, Blumenfeld, \& Paris, 2004), and the other approach is characterised by vigor, dedication, and absorption (Schaufeli, Salanova, Gonzalez-Rom, \& Bakker, 2002). Further, the association between these two models and students' performance is discussed.
\end{abstract}

Keywords: academic engagement, definitions of academic engagement, dimensions of academic engagement, conceptualisations of academic engagement

\section{Introduction}

Over the last seven decades, researchers and educators have exhibited a growing interest in the concept of engagement as a way to improve disaffection, to avert student boredom, to enhance students' motivation and involvement in school-related activities, to increase successful student achievement levels, and to understand students' positive development (Appleton, Christenson, \& Furlong, 2008; Carter, Reschly, Lovelace, Appleton, \& Thompson, 2012; Fredricks et al., 2004; Li \& Lerner, 2011; National Research Council \& Institute of Medicine, 2004; Upadyaya \& Salmela-Aro, 2013). Engagement is also a valuable construct for capturing the gradual process by which students drop out from school (Appleton et al., 2008; Appleton, Christenson, Kim, \& Reschly, 2006; Finn, 1989). Given that students' dropping out from school is not an instantaneous event, but rather a gradual process that happens over time, researchers and educators alike view engagement as the main theoretical model for intervening with and understanding potential dropouts to enhance positive performance and encourage school completion (Appleton et al., 2008; Appleton et al., 2006).

\section{What Is Engagement?}

Engagement is a complex term that emphasises students' various patterns in motivation, cognition, and behaviour (Appleton et al., 2008; Baron \& Corbin, 2012; Fredricks et al., 2004; Phan \& Ngu, 2014a; Sharma \& Bhaumik, 2013). Researchers have investigated the construct extensively in the last seven decades, and the literature generally reflects substantial variations in its terms, definitions, and coverage (Appleton et al., 2008; Baron \& Corbin, 2012; Fredricks et al., 2004; Klem \& Connell, 2004; Sharma \& Bhaumik, 2013; Upadyaya \& Salmela-Aro, 2013). Different researchers have offered various terms and coverage of engagement such as school engagement (e.g., Fredricks et al., 2004), study engagement (e.g., Schaufeli et al., 2002), and student course engagement (e.g., Handelsman, Briggs, Sullivan, \& Towler, 2005). Examples of these variations and their corresponding definitions offered by scholars in the literature are provided in Table 1. 
Table 1. Examples of variations in terms and definitions of engagement

\begin{tabular}{|c|c|c|}
\hline Authors & Construct Name & Definition \\
\hline Audas \& Willms (2002) & Engagement & $\begin{array}{l}\text { The extent to which a student participates in academic- and } \\
\text { non-academic-related activities as well as identifies with and values the goals of } \\
\text { studying. }\end{array}$ \\
\hline $\begin{array}{l}\text { Skinner, Kindermann, \& Furrer } \\
\text { (2009) }\end{array}$ & Engagement & $\begin{array}{l}\text { The quality of students' participation or connection with the schooling } \\
\text { endeavour and hence with activities, values, people, goals, and place that } \\
\text { comprise it. }\end{array}$ \\
\hline $\begin{array}{l}\text { Skinner, Wellborn, \& Connell } \\
\text { (1990) }\end{array}$ & Engagement & $\begin{array}{l}\text { A student's initiation of effort, action, and persistence in schoolwork as well as } \\
\text { his ambient emotional states during learning activities. }\end{array}$ \\
\hline Willms (2003) & $\begin{array}{l}\text { Student Engagement } \\
\text { at School }\end{array}$ & $\begin{array}{l}\text { The extent to which a student values school-related outcomes and identifies with } \\
\text { and participates in academic and non-academic school activities. }\end{array}$ \\
\hline $\begin{array}{l}\text { Newmann, Wehlage, \& Lamborn } \\
\text { (1992) }\end{array}$ & $\begin{array}{l}\text { Student Engagement } \\
\text { in Academic Work }\end{array}$ & $\begin{array}{l}\text { Students' psychological effort and investment toward learning, understanding, } \\
\text { or mastering the skills, crafts, or knowledge that the schoolwork is intended to } \\
\text { promote. }\end{array}$ \\
\hline $\begin{array}{l}\text { Wehlage, Rutter, Smith, Lesko, } \\
\text { \& Fernandez (1989) }\end{array}$ & $\begin{array}{l}\text { Educational } \\
\text { Engagement }\end{array}$ & $\begin{array}{l}\text { The psychological investment needed to master and understand skills and } \\
\text { knowledge explicitly taught in educational institutions. }\end{array}$ \\
\hline Kuh (2003) & Student Engagement & $\begin{array}{l}\text { The energy and time a student devotes to educational sound activities outside } \\
\text { and inside classrooms, and practices and policies that educational institutions } \\
\text { use to encourage the student to participate in these activities. }\end{array}$ \\
\hline $\begin{array}{l}\text { Schaufeli, Salanova, } \\
\text { Gonzalez-Rom, \& Bakker (2002) }\end{array}$ & Study Engagement & $\begin{array}{l}\text { A fulfilling and positive study-related state of mind that is characterised by } \\
\text { absorption, vigor, and dedication. }\end{array}$ \\
\hline $\begin{array}{l}\text { Christenson, Reschly, Appleton, } \\
\text { Berman-Young, Spanjers \& } \\
\text { Varro (2008) }\end{array}$ & Student Engagement & $\begin{array}{l}\text { Students' investment in and commitment to learning, belonging and } \\
\text { identification at school, and participation in the institution environment and } \\
\text { initiation of activities to achieve an outcome. }\end{array}$ \\
\hline
\end{tabular}

Table 1 shows, as mentioned earlier, some examples of a plethora of engagement terms and definitions. Despite their variations, some similar themes have been noted between the definitions across the researchers. For example, the definitions proposed by Audas and Willms (2002), Skinner et al. (2009), Skinner et al. (1990), and Willms (2003) emphasised students' participation and identification with school and school-related activities. The definitions by Newmann et al. (1992) and Wehlage et al. (1989) drew a link between engagement and students' psychological investment in learning. While Kuh's (2003) definition of the concept focused upon the link between engagement and energy, Schaufeli et al. (2002) emphasised students' motivational mindset related to their study activities that is characterised by dedication, vigor, and absorption. Christenson et al. (2008), in turn, have outlined a general definition of the notion, involving aspects mentioned in the earlier definitions and emphasising students' participation, commitment, investment, and identification with schooling and school-related activities. Finally, while a myriad of terms and definitions have been proffered, engagement is broadly a positive and proactive term that captures students' quality of participation, investment, commitment, and identification with school and school-related activities to enhance students' performance.

\section{Dimensions of Engagement}

Although engagement is relatively diverse in its definitions and coverage, researchers have reached a consensus that the construct is multidimensional and encompasses different aspects (e.g., behavioural, cognitive, and emotional), operating together to reflect students' positive approach to learning (Appleton et al., 2008; Carter et al., 2012; Fredricks et al., 2004; Phan, 2014b; Schaufeli et al., 2002; Upadyaya \& Salmela-Aro, 2013). However, researchers have consistently disagreed on the types and number of the dimensions of engagement (Appleton et al., 2008; Fredricks et al., 2004; Li \& Lerner, 2011; Schaufeli et al., 2002). For example, the work of Schaufeli et al. (2002) conceptualised engagement as having three dimensions (i.e., vigor, dedication, and absorption), as opposed to Willms (2003) who identified two components of the construct (i.e., behavioural and psychological). Table 2 presents some examples of the variations in number and types of dimensions that researchers have proposed in their models for the construct. 
Table 2. Dimensional variations across models of engagement

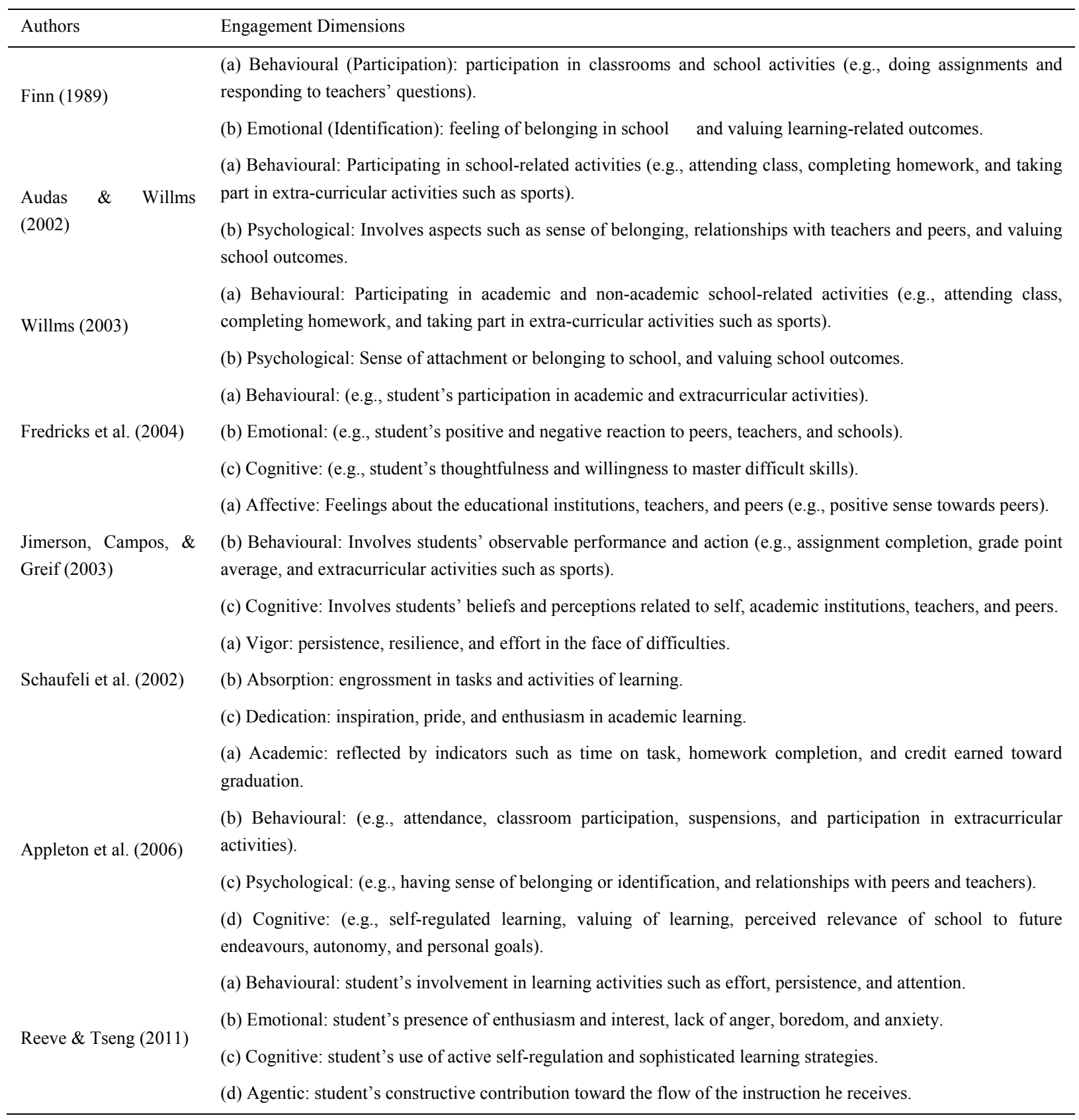

Based on Table 2, engagement is typically conceptualised as having two, three, or four dimensions. Researchers (e.g., Audas \& Willms, 2002; Finn, 1989, Willms, 2003) adopting a two-dimensional model have included behavioural (e.g., participation in academic and non-academic activities) and psychological (e.g., identification with school, valuing learning outcomes, and belonging) subtypes in their conceptualisation of the construct (Appleton et al., 2008). Fredricks et al. (2004) and Jimerson et al. (2003) have proposed a tripartite model that includes a cognitive dimension (e.g., thoughtfulness and willingness to master difficult tasks), as well as the psychological and behavioural subtypes. Schaufeli et al. (2002), similarly, adopted three dimensions, but labelled these components as dedication, vigor, and absorption (Appleton et al., 2008; Bakker, Vergel, \& Kuntze, 2015; Tuominen-Soini \& Salmela-Aro, 2014; Upadyaya \& Salmela-Aro, 2013). Appleton et al. (2006) and Reeve and Tseng (2011) have, in addition, proposed a fourth dimension of engagement. Appleton et al. (2006) called the fourth dimension 'academic engagement', which includes aspects such as completing assignments and time on task. However, most previous studies have subsumed this dimension (i.e., academic) under behavioural engagement (Appleton et al., 2008; Coleman, 2012; Fredricks \& McColskey, 2012). On the other hand, Reeve 
and Tseng (2011) proposed the agentic dimension as a new aspect of the engagement construct; however, much more research is required to validate this new concept (Sinatra, Heddy, \& Lombardi, 2015).

While theorists have posited conceptualisations of engagement with two, three, and four sub-dimensions, the models of Fredricks et al. (2004) (also called the North American model) and Schaufeli et al. (2002) (known as the European approach of engagement) (Upadyaya \& Salmela-Aro, 2013) have been pivotal in understanding the multidimensional nature of the engagement construct. The importance of these two models is that the engagement construct addresses central and related facets of individual development (i.e., motivation, cognition, and behaviour), unlike other models (e.g., Finn, 1989; Willms, 2003) that lack, for example, the emphasis on one of these facets (i.e., cognition) (Archambault, Janosz, Fallu, \& Pagani, 2009; Phan \& Ngu, 2014a). In addition, these two models have been widely adopted, and received considerable attention in terms of validation and empirical examination (e.g., Archambault, Janosz, Morizot, \& Pagani, 2009; Breso, Schaufeli, \& Salanova, 2011; Janosz, Archambault, Morizot, \& Pagani, 2008; Mo \& Singh, 2008; Phan, 2014a, 2014c; Phan \& Ngu, 2014a; Salmela-Aro, Tolvanen, \& Nurmi, 2009; Salmela-Aro \& Upadyaya, 2014; Vasalampi, Salmela-Aro, \& Nurmi, 2009; Wang \& Fredricks, 2014; Wang, Willett, \& Eccles, 2011). The following paragraphs provide additional detail about each model.

\section{Fredricks et al.'s (2004) Model of Engagement}

In their comprehensive review of engagement literature, Fredricks et al. (2004) described engagement as a malleable, developing, and multidimensional construct that consists of three broad dimensions: behavioural, cognitive, and emotional. The dimensions, according to the authors, are not isolated but interrelate with each other.

\subsection{Behavioural Engagement}

According to Fredricks et al. (2004), three ways are commonly utilised in defining behavioural engagement (Finn 1993; Finn, Pannozzo, \& Voelkl, 1995; Finn \& Rock, 1997; Skinner \& Belmont, 1993), which Rumberger (2004) found to be a crucial factor in mediating the dropout process. The first way involves positive conduct, such as adhering to the norms of the classroom, following the rules, and refraining from engaging in disruptive behaviours (e.g., being troublesome or skipping school) (Finn \& Rock, 1997; Fredricks et al., 2004). The second way pertains to participation in learning and academic-related tasks, and involves behaviours such as discussion contribution, asking questions, paying attention, concentrating, exhibiting persistence, and putting forth effort (Fredricks et al., 2004; Finn et al., 1995; Skinner \& Belmont, 1993). The third and last way, according to Finn (1993) and Finn et al. (1995), is the involvement in activities related to school that include, for example, school governance and sports (Fredricks et al., 2004). Therefore, behavioural engagement is a directly observable dimension of engagement, and the salient indicators of this dimension include truancy, preparation for school, attendance, participation in curricular and extracurricular tasks, and discipline referrals (Appleton et al., 2008; Fredricks et al., 2004; Reschly \& Christenson, 2006).

\subsection{Cognitive Engagement}

The cognitive engagement dimension refers to students' investment in learning, and involves aspects such as willingness and thoughtfulness to expend the effort required to understand and master difficult tasks, the use of appropriate learning strategies (e.g., students' use of elaboration rather than memorisation), challenge preference, and self-regulation (Fredricks et al., 2004). Indicators of cognitive engagement include asking questions for clarification of ideas, persistence in difficult activities, flexibility in problem solving, use of learning strategies (e.g., relating new information to existing information), and use of self-regulation to support learning (Finn \& Zimmer, 2012; Fredricks et al., 2004).

\subsection{Emotional Engagement}

Scholars have variously identified emotional engagement as motivational engagement (e.g., Linnenbrink \& Pintrich, 2003), psychological engagement (e.g., Finn, 1993), and affective engagement (e.g., Archambault et al., 2009). However, all of these terms refer to the same features of emotional engagement, which describes students' positive and negative emotional reactions toward teachers, classmates, academic works, and school in general (Fredricks et al., 2004). It includes indicators such as the presence of interest and happiness and the lack of boredom, anxiety, and sadness. Further, students exhibiting emotional engagement have a sense of identification with and belonging to the school, value school outcomes, and feel as though they are supported by their peers and teachers (Fredricks et al., 2004).

\section{Schaufeli et al.'s (2002) Model of Engagement}

Engagement, according to Schaufeli et al. (2002), is defined as a fulfilling and positive study-related state of 
mind that is characterised by three dimensions: absorption, vigor, and dedication (Schaufeli et al., 2002). Initially, the notion of engagement was conceptualised as work-related engagement, but recently this concept has been expanded to include the notion of study engagement (Ouweneel, Le Blanc, \& Schaufeli, 2014; Schaufeli et al., 2002; Upadyaya \& Salmela-Aro, 2013). Schaufeli and his colleagues (e.g., Breso et al., 2011; Ouweneel, Le Blanc, \& Schaufeli, 2011; Ouweneel, Schaufeli, \& Le Blanc, 2013) have argued that, from a psychological point of view, a student's tasks and activities can be considered 'work'. Like an employee, the student is involved in coercive, structured tasks and activities (e.g., completing assignments and projects, attending class) that are targeted toward a particular aim (e.g., passing examinations, getting job) (Ouwneel et al., 2013; Ouwneel et al., 2011). Therefore, educational places are settings in which students work, so it is reasonable that the concept of engagement can be extended to the study context (Ouwneel et al., 2013; Ouwneel et al., 2011; Salmela-Aro \& Upadaya, 2012). Thus, analogously to work engagement, study engagement is characterised by students' feelings of vigor, their dedication to their studies, and their absorption in their academic-related tasks and activities (Schaufeli et al., 2002; Ouwneel et al., 2013; Ouwneel et al., 2011). The following paragraph discusses in more detail the three dimensions of engagement: vigor, dedication, and absorption.

The first dimension, vigor, refers to students' sense of high levels of mental resilience and energy while studying, their willingness to exert and invest effort into their academic-related activities, their persistence in the face of obstacles, and their positive approach to learning (Ouweneel et al., 2014; Ouweneel et al., 2013; Salmela-Aro \& Upadyaya, 2014; Upadyaya \& Salmela-Aro, 2013). The second dimension, dedication, is characterised by students' sense of enthusiasm, inspiration, significance, challenge, and pride for engaging in their studies, as well as their perception of school-related activities as meaningful (Ouweneel et al., 2013; Ouweneel et al., 2014; Salmela-Aro \& Upadyaya, 2014; Upadyaya \& Salmela-Aro, 2013). Finally, absorption is defined as students' sense of being deeply engrossed and fully concentrated in their studies (e.g., time passes quickly when studying) (Ouweneel et al., 2013; Ouweneel et al., 2014; Salmela-Aro \& Upadyaya, 2014; Upadyaya \& Salmela-Aro, 2013). The three aforementioned dimensions of engagement are separate constructs, but also correlate highly with each other (Schaufeli et al., 2002; Tuominen-Soini \& Salmela-Aro, 2014; Upadyaya \& Salmela-Aro, 2013).

\section{Comparison between Models of Engagement by Fredricks et al. (2004) and Schaufeli et al. (2002)}

Both engagement models (i.e., Fredricks et al., 2004; Schaufeli et al., 2002) measure different features of students' underlying academic engagement, and emphasise the association between academic engagement and successful achievements (Phan, 2014a, 2014b; Upadyaya \& Salmela-Aro, 2013). Our critical examination of the literature concerning these two models indicates that the two conceptualisations have some major similarities and differences. The following paragraphs highlight the main similarities and differences of these two models.

Despite the variations between the two conceptualisations, researchers have observed some similarities (Bakker et al., 2015; Phan, 2014c; Upadyaya \& Salmela-Aro, 2013). For example, the two models include aspects such as students' resilience, willingness to exert effort, persistence, challenge preference, and positive approach toward learning in their definitions of the multidimensional components of engagement. In addition, within Fredricks et al.'s (2004) framework, students' cognitive engagement involves items such as their investment in school-related activities and willingness to learn, which is similar to the enthusiasm and inspiration described by Schaufeli et al. (2002) in the dedication dimension (Tuominen-Soini \& Salmela-Aro, 2014; Upadyaya \& Salmela-Aro, 2013). Furthermore, Schaufeli et al.'s (2002) description of vigor includes a positive approach to school-related activities, which is similar to the emotional dimension aspects such as positive feelings about school and enjoyment in the Fredricks et al. (2004) model (Tuominen-Soini \& Salmela-Aro, 2014; Upadyaya \& Salmela-Aro, 2013). Likewise, Schaufeli et al.'s (2002) absorption shares some features with the behavioural dimension and involvement in learning in the Fredricks et al. (2004) model, as it describes a student's behavioural performance and total concentration on study-related activities (Tuominen-Soini \& Salmela-Aro, 2014; Upadyaya \& Salmela-Aro, 2013).

Even though the two conceptualisations of engagement have several similarities, they also have some differences. The main difference between the two conceptualisations is that dedication, absorption, and vigor in Schaufeli et al. (2002) describe students' psychological engagement rather than their behaviour in the school environment (Upadyaya \& Salmela-Aro, 2013; Schaufeli et al., 2002). As a result, Schaufeli et al.'s (2002) model lacks information pertaining, for example, to school attendance, adherence to classroom norms, following the rules, and respect for teaching staff (Upadyaya \& Salmela-Aro, 2013). In addition, the emotional dimension of Schaufeli et al.'s (2002) model regards students' feelings toward their studies only, and does not concern their feelings about classmates, teachers, and the school (Upadyaya \& Salmela-Aro, 2013). Despite these omissions, however, the description of students' psychological engagement in great detail increases the significance of the Schaufeli et al. (2002) model; providing new information and a fresh basis for researchers to gauge the 
motivational approach of engagement (Phan \& Ngu, 2014a; Phan, 2014b; Upadyaya \& Salmela-Aro, 2013).

\section{Engagement and Students' Achievement}

Students' achievement has typically been measured with standardised tests, performance test scores, academic grades, and GPA (Grade Point Average) (Finn \& Rock, 1997; Fredricks et al., 2004; Upadyaya \& Salmela-Aro, 2013). Empirical studies have validated both conceptualisations of engagement (Fredricks et al., 2004; Schaufeli et al., 2002) and found them to relate to students' performance at all educational levels: the more engagement students experience, the better they perform in their academic achievement.

\subsection{The Association between Behavioural, Emotional, and Cognitive Dimensions of Engagement and Students' Performance}

Empirical studies using cross-sectional and longitudinal research designs have established the influence of behavioural, cognitive, and emotional engagement on students' performance outcomes. These empirical studies have explored the dimensions (i.e., behavioural, cognitive, and emotional) separately from each other, or combined them in one single scale. From a cross-sectional perspective, for instance, Dogan's (2015) study involving 578 intermediate and high school students found that cognitive engagement positively predicted academic performance $(\beta=.49, p<.05)$. Lee's $(2014)$ study among 3268 secondary school students has similarly shown that both emotional $(\beta=.037, p<.05)$ and behavioural $(\beta=.106, p<.001)$ engagement significantly predicted students' reading performance. In addition, Lee also noted that behavioural engagement partially mediated the effect of emotional engagement on reading performance $(\beta=.49, p<.001)$. Likewise, Dotterer and Lowe (2011) conducted a study among $10145^{\text {th }}$ grade elementary students. The authors reported that cognitive and emotional engagement (combined as a unitary construct) and behavioural engagement predicted students' achievement $[(\beta=.15, p<.05),(\beta=.14, p<.05)$, respectively]. In a similar vein, the findings of a study by Perry, Liu and Pabian (2010) involving 285 intermediate and high school students indicated that a combination of emotional and behavioural engagement significantly predicted students' grades $(\beta=.37, p<.001)$. In addition, Mo and Singh (2008) have also provided evidence for the positive contribution of behavioural $(\beta=.28)$, emotional $(\beta=.04)$, and cognitive $(\beta=.20)$ engagement on students' performance outcomes among 1971 intermediate school students.

The impact of the three aforementioned dimensions of engagement on students' performance has been also evident from longitudinal data. For example, Chase et al.'s (2014) three-wave study over three years with 710 secondary students (grades 10-12) has provided evidence for the positive reciprocal relationships between cognitive, emotional, and behavioural dimensions of engagement and academic performance operationalized by GPA. From engagement to GPA, Chase and his colleagues noted that grade 10 behavioural engagement significantly predicted grade 12 GPA $(\beta=.19, p<.05)$, and grade 10 emotional engagement also strongly predicted grade $11 \mathrm{GPA}(\beta=.08, p<.05)$. From GPA to engagement, the authors indicated that grade $10 \mathrm{GPA}$ significantly contributed to grade 11 cognitive engagement $(\beta=.14, p<.05)$, grade 12 behavioural engagement $(\beta=.21, p<.05)$, and grade 12 emotional engagement $(\beta=.11, p<.015)$. Similarly, Wang and Holcombe's (2010) two-wave study with 1046 junior school students has shown that Time 2 behavioural $(\beta=.13, p<.05)$, emotional $(\beta=.32, p<.05)$, and cognitive subtypes of engagement $(\beta=.17, p<.05)$ significantly impacted students' GPA.

In a similar vein, empirical studies (e.g., Wang \& Eccles, 2012a) have explored trajectories of behavioural, emotional, and cognitive dimensions of engagement, and their relationships to students' achievement. Reeve and Lee (2014) involved 313 secondary school students in a study with data collected at three time points over a semester. Reeve and Lee (2014) found that changes in academic engagement (combined measures of emotional, behavioural, cognitive, and agentic engagement) at Time 2 (after controlling for engagement at Time 1) predicted students' achievement at Time $3(\beta=.22, p<.05)$. Additionally, Wang and Eccles $(2012 \mathrm{a})$, in a three-wave study (at the $7^{\text {th }}, 9^{\text {th }}$, and $11^{\text {th }}$ grades of school) among 1148 students, noted that behavioural, emotional, and cognitive engagement decreased across the three time points, and the declines in behavioural and cognitive engagement were positively associated with declines in students' GPA. Likewise, Li and Lerner (2011) examined, with 1977 students, changes in behavioural and emotional engagement at four time points (across grades 5-8) and their links to students' grades. The authors reported that both dimensions of engagement changed across the four time points (mostly downward trends), and importantly these trajectories were significantly associated with students' grades.

\subsection{The Association between Vigor, Dedication, and Absorption Dimensions of Engagement and Students'} Performance

Similar to Fredricks et al.'s (2004) model, the three dimensions of Schaufeli et al.'s (2002) conceptualisation of 
engagement have been demonstrated by correlational and longitudinal studies (e.g., Phan \& Ngu, 2014b; Phan, $2014 \mathrm{c}$ ) to be robust predictors of students' achievement outcomes. From a correlational perspective, for example, Phan and Ngu (2014b) conducted a study among 294 university students, and found that vigor, dedication, and absorption (combined as a unitary construct) significantly predicted students' performance $(\beta=.54, p<.001)$. Casuso-Holgado et al.'s (2013) study similarly showed, among 304 university students, that vigor, dedication, and absorption were strongly associated with students' GPA. Salanova, Schaufeli, Martinez, and Breso (2010) included 527 university students in a study that found that vigor and dedication as a unitary construct significantly predicted students' (GPA) $(\beta=.11, p<.05)$.

Longitudinal studies (e.g., Breso et al., 2011) have also provided evidence for the positive impact of vigor, dedication, and absorption on students' performance over time. For example, Phan and Ngu's (2014a) multi-wave study among 326 high school students found that Time 3 absorption $(\beta=.14, p<.05)$, vigor $(\beta=.12, p<.01)$, and dedication $(\beta=.10, p<.05)$ positively impacted students' course marks at Time 5 . Phan's (2014c) four-wave study with 249 high school students similarly revealed that absorption at Time 2 exerted a positive impact on achievement at Time $4(\beta=.12, p<.001)$. Additionally, in a two-wave study involving 1530 upper-secondary and vocational students, Salmela-Aro and Upadaya (2012) noticed that students' GPA was positively associated with vigor, dedication, and absorption at both time points. In a similar vein, Breso et al.'s (2011) quasi-experimental longitudinal study with 71 university students has shown that increases in vigor and dedication as a unitary construct were aligned with similar increases in students' performance.

\subsection{In Totality}

Despite the modest variations described earlier in the terms and definitions of the two conceptualisations (Fredricks et al., 2004; Schaufeli et al., 2002), there is clear and consistent evidence for the positive short-term and/or long-term influences of their dimensions on students' academic achievement. Positively, this inference supports the argument by Appleton et al. (2008) that, regardless of the various conceptualizations of engagement, there is strong empirical support for the impact of the construct on students' performance.

Apart from the effect on students' achievement, the results of the longitudinal studies (e.g., Breso et al., 2011; Wang \& Eccles, 2012a) described above based on both conceptualizations indicated that the engagement construct is changeable and malleable. Educationally, based on this credence, it is important for researchers and educators to consider factors that might help heighten and foster students' engagement in school and academic-related activities which, eventually, enhance students' performance outcomes. A plethora of empirical studies have suggested a number of motivational and social antecedents that could encourage and cultivate students' proactive engagement. Motivational antecedents include, for example, self-efficacy (e.g., Breso et al., 2011; Phan, 2014c; Phan \& Ngu, 2014a; Ouweneel et al., 2013; Reeve \& Lee, 2014; Phan, 2014b; Wang \& Eccles, 2013), task value (e.g., Wang \& Eccles, 2013; Martin, Way, \& Anderson, 2015; Phan \& Ngu, 2014b; Fan, 2011), and mastery goal orientation (e.g., Wang \& Holcombe, 2010; Reeve \& Lee, 2014; Phan, 2014a; Gonida, Voulala, \& Kiosseoglou, 2009). In addition, empirical findings have produced salient social antecedents of engagement that include, for example, parents' and teachers' support (e.g., Perry, Liu, \& Pabian, 2010; Wang \& Holcombe, 2010; Wang \& Eccles, 2013; Brewster \& Bowen, 2004; Wang \& Eccles, 2012b; Estell \& Perdue, 2013).

Consequently, it seems important that teaching practices and/or educational intervention targeted to enhance engagement consider strategies that facilitate and promote the abovementioned antecedents of the construct. Mechanisms that could heighten self-efficacy include positive feedback and encouragement, reinforcement of students' previous success and mastery, and the use of social comparison and role modelling (Bandura, 1986, 1997; Caraway, Tucker, Reinke, \& Hall, 2003; Phan \& Ngu, 2014a; Schunk, 1981, 1987; Schunk \& Hanson, 1985). In turn, the enhancement of mastery goals involves emphasizing students' mastery and self-improvement (Lee, 2014; Wang \& Holcombe, 2010), while task value could be enhanced through strategies such as clarification of the utility of a subject matter (e.g., mathematics) and explaining the potential relevance of the subject matter to the students' future (e.g., career choices) (Neuville, Frenay, \& Bourgeois, 2007; Phan, 2014a). Concerning social factors, mechanisms for teachers' support incorporate, for example, developing good and supportive relationships with students, praising students' effort, showing interest in students, holding high expectations for students, and providing students with opportunities to interact with each other (Fall \& Roberts, 2012; Lee, 2014; Patrick, Ryan, \& Kaplan, 2007). Parental support encompasses, for example, parents frequently discussing school-related topics with their children, offering positive reinforcement about school activities, and contributing to students' sense of identification with schools (Caraway et al., 2003; Fall \& Roberts, 2012). 


\section{Conclusion}

In summary, this article has provided a review of the concept of engagement. Our examination of the literature briefly focused on the similarities and differences between the various terms, definitions, and dimensions offered by researchers for the construct. The scope of this review has also provided a short emphasis on two major conceptualisations of the notion of engagement (the North American Model of Engagement by Fredricks et al., 2004, and the European Approach of Engagement by Schaufeli et al., 2002). The literature examined in this review suggests that both broad models have demonstrated strong associations with students' academic performance, supporting the arguments by researchers (e.g., Appleton et al., 2008; Klem \& Connel, 2004) that, at the core of many models, the concept of engagement captures students' quality learning. Further, the current longitudinal research studies described in this review have provided support for the malleability and/or development of the notion, proposing a direction for intervention. Hence, fostering students' motivation (e.g., self-efficacy) and social factors (e.g., teacher support) is one pathway to heighten and enhance students' proactive engagement in school and academic-related activities.

\section{References}

Appleton, J. J., Christenson, S. L., \& Furlong, M. J. (2008). Student engagement with school: Critical conceptual and methodological issues of the construct. Psychology in the Schools, 45(5), 369-386. http://dx.doi.org/10.1002/pits.20303

Appleton, J. J., Christenson, S. L., Kim, D., \& Reschly, A. L. (2006). Measuring Cognitive and Psychological Engagement: Validation of the Student Engagement Instrument. Journal of School Psychology, 44(5), 427-445. http://dx.doi.org/10.1016/j.jsp.2006.04.002

Archambault, I. P., Janosz, M. P., Morizot, J. P., \& Pagani, L. P. (2009). Adolescent Behavioral, Affective, and Cognitive Engagement in School: Relationship to Dropout. The Journal of School Health, 79(9), 408. http://dx.doi.org/10.1111/j.1746-1561.2009.00428.x

Archambault, I., Janosz, M., Fallu, J.-S., \& Pagani, L. S. (2009). Student Engagement and Its Relationship with Early High School Dropout. Journal of Adolescence, 32(3), 651-670. http://dx.doi.org/10.1016/j.adolescence.2008.06.007

Audas, R., \& Willms, J. D. (2002). Engagement and dropping out of school: A life-course perspective. Applied Research Branch, Human Resources Development Canada. Retrieved March 15, 2015 from http://sbisrvntweb.uqac.ca/archivage/15292281.pdf

Bakker, A. B., Vergel, A. I. S., \& Kuntze, J. (2015). Student engagement and performance: A weekly diary study on the role of openness. Motivation and Emotion, 39(1), 49-62. http://dx.doi.org/10.1007/s11031-014-9422-5

Bandura, A. (1986). Social founations of thought and action: A social cognitive theory. Englewood Cliffs, NJ: Prentice-Hall.

Bandura, A. (1997). Self-efficacy: The exercise of control. New York, NY: W.H. Freeman.

Baron, P., \& Corbin, L. (2012). Student engagement: Rhetoric and reality. Higher Education Research \& Development, 31(6), 759-772. http://dx.doi.org/10.1080/07294360.2012.655711

Bresó, E., Schaufeli, W. B., \& Salanova, M. (2011). Can a self-efficacy-based intervention decrease burnout, increase engagement, and enhance performance? A quasi-experimental study. Higher Education, 61(4), 339-355. http://dx.doi.org/10.1007/s10734-010-9334-6

Brewster, A. B., \& Bowen, G. L. (2004). Teacher support and the school engagement of Latino middle and high school students at risk of school failure. Child and Adolescent Social Work Journal, 21(1), 47-67. http://dx.doi.org/10.1023/B:CASW.0000012348.83939.6b

Caraway, K., Tucker, C. M., Reinke, W. M., \& Hall, C. (2003). Self-efficacy, goal orientation, and fear of failure as predictors of school engagement in high school students. Psychology in the Schools, 40(4), 417-427. http://dx.doi.org/10.1002/pits.10092

Carter, C. P., Reschly, A. L., Lovelace, M. D., Appleton, J. J., \& Thompson, D. (2012). Measuring student engagement among elementary students: Pilot of the Student Engagement Instrument-Elementary Version. School Psychology Quarterly, 27(2), 61-73. http://dx.doi.org/10.1037/a0029229

Casuso-Holgado, M. J., Cuesta-Vargas, A. I., Moreno-Morales, N., Labajos-Manzanares, M. T., Barón-López, F. J., \& Vega-Cuesta, M. (2013). The association between academic engagement and achievement in health 
sciences students. BMC medical education, 13(1), 33. http://dx.doi.org/10.1186/1472-6920-13-33

Chase, P. A., Hilliard, L. J., Geldhof, G. J., Warren, D. J., \& Lerner, R. M. (2014). Academic achievement in the high school years: The changing role of school engagement. Journal of Youth and Adolescence, 43(6), 884-896. http://dx.doi.org/10.1007/s10964-013-0085-4

Christenson, S. L., Reschly, A. L., Appleton, J. J., Berman-Young, S., Spangers, D., \& Varro, P. (2008). Best practices in fostering student engagement. In A. Thomas, \& J. Grimes (Eds.), Best practices in school psychology V (pp. 1099-1120). Washington, DC: National Association of School Psychologists.

Coleman, S. (2012). Examining a strengths-based approach to promoting students' engagement with school: A pilot study (Unpublished doctoral dissertation). University of Missouri, Columbia.

Dogan, U. (2015). Student Engagement, Academic Self-efficacy, and Academic Motivation as Predictors of Academic Performance. Anthropologist, 20(3), 553-561. Retrieved from http://search.proquest.com.ezproxy.une.edu.au/docview/1718083542? accountid=17227

Dotterer, A. M., \& Lowe, K. (2011). Classroom context, school engagement, and academic achievement in early adolescence. Journal of Youth and Adolescence, 40(12), 1649-1660. http://dx.doi.org/10.1007/s10964-011-9647-5

Estell, D. B., \& Perdue, N. H. (2013). Social support and behavioral and affective school engagement: The effects of peers, parents, and teachers. Psychology in the Schools, 50(4), 325-339. http://dx.doi.org/10.1002/pits.21681

Fall, A.-M., \& Roberts, G. (2012). High school dropouts: Interactions between social context, self-perceptions, school engagement, and student dropout. Journal of Adolescence, 35(4), 787-798. http://dx.doi.org/10.1016/j.adolescence.2011.11.004

Fan, W. (2011). Social influences, school motivation and gender differences: An application of the $\begin{array}{lllll}\text { expectancy-value theory. } & \text { Educational } & \text { Psychology, } & 31(2), & \text { 157-175. }\end{array}$ http://dx.doi.org/10.1080/01443410.2010.536525

Finn, J. D. (1989). Withdrawing from School. Review of Educational Research, 59(2), 117. http://dx.doi.org/10.3102/00346543059002117

Finn, J. D. (1993). School engagement and students at risk. Washington, DC: National Center for Education Statistics.

Finn, J. D., \& Rock, D. A. (1997). Academic success among students at risk for school failure. Journal of Applied Psychology, 82(2), 221-234. http://dx.doi.org/10.1037/0021-9010.82.2.221

Finn, J. D., \& Zimmer, K. S. (2012). Student engagement: What is it? Why does it matter? Handbook of research on student engagement (pp. 97-131). Springer. http://dx.doi.org/10.1007/978-1-4614-2018-7_5

Finn, J. D., Pannozzo, G. M., \& Voelkl, K. E. (1995). Disruptive and inattentive-withdrawn behavior and achievement among fourth graders. The Elementary School Journal, 95(5), 421-434. http://dx.doi.org/10.1086/461853

Fredricks, J. A., Blumenfeld, P. C., \& Paris, A. H. (2004). School Engagement: Potential of the Concept, State of the Evidence. Review of Educational Research, 74(1), 59-109. http://dx.doi.org/10.3102/00346543074001059

Fredricks, J., \& McColskey, W. (2012). The Measurement of Student Engagement: A Comparative Analysis of Various Methods and Student Self-report Instruments. In S. L. Christenson, A. L. Reschly, \& C. Wylie (Eds.), Handbook of Research on Student Engagement (pp. 763-782). Springer US. http://dx.doi.org/10.1007/978-1-4614-2018-7_37

Gonida, E. N., Voulala, K., \& Kiosseoglou, G. (2009). Students' achievement goal orientations and their behavioral and emotional engagement: Co-examining the role of perceived school goal structures and parent goals during adolescence. Learning and Individual Differences, 19(1), 53-60. http://dx.doi.org/10.1016/j.lindif.2008.04.002

Handelsman, M. M., Briggs, W. L., Sullivan, N., \& Towler, A. (2005). A measure of college student course engagement. The Journal of Educational Research, 98(3), 184-192. http://dx.doi.org/10.3200/JOER.98.3.184-192

Janosz, M., Archambault, I., Morizot, J., \& Pagani, L. S. (2008). School Engagement Trajectories and Their 
Differential Predictive Relations to Dropout. The Journal of Social Issues, 64(1), 21. http://dx.doi.org/10.1111/j.1540-4560.2008.00546.x

Jimerson, S. R., Campos, E., \& Greif, J. L. (2003). Toward an Understanding of Definitions and Measures of School Engagement and Related Terms. California School Psychologist, 8, 7-27. http://dx.doi.org/10.1007/BF03340893

Klem, A. M., \& Connell, J. P. (2004). Relationships matter: Linking teacher support to student engagement and $\begin{array}{lllll}\text { achievement. } \quad \text { Journal } & \text { of health, } & 74(7), & \end{array}$ http://dx.doi.org/10.1111/j.1746-1561.2004.tb08283.x

Kuh, G. D. (2003). What We're Learning About Student Engagement From NSSE: Benchmarks for Effective Educational Practices. Change: The Magazine of Higher Learning, 35(2), 24-32. http://dx.doi.org/10.1080/00091380309604090

Lee, J.-S. (2014). The Relationship Between Student Engagement and Academic Performance: Is It a Myth or Reality? The Journal of Educational Research, 107(3), 177-185. http://dx.doi.org/10.1080/00220671.2013.807491

Li, Y., \& Lerner, R. M. (2011). Trajectories of school engagement during adolescence: Implications for grades, depression, delinquency, and substance use. Developmental Psychology, 47(1), 233-247. http://dx.doi.org/10.1037/a0021307

Linnenbrink, E. A., \& Pintrich, P. R. (2003). The role of self-efficacy beliefs in student engagement and learning in the classroom. Reading \& Writing Quarterly: Overcoming Learning Difficulties, 19(2), 119-137. http://dx.doi.org/10.1080/10573560308223

Martin, A. J., Way, J., Bobis, J., \& Anderson, J. (2015). Exploring the ups and downs of mathematics engagement in the middle years of school. The Journal of Early Adolescence, 35(2), 199-244. http://dx.doi.org/10.1177/0272431614529365

Mo, Y., \& Singh, K. (2008). Parents' Relationships and Involvement: Effects on Students' School Engagement and Performance. RMLE Online: Research in Middle Level Education, 31(10), 1-11. http://dx.doi.org/10.1080/19404476.2008.11462053

National Research Council \& Institute of Medicine. (2004). Engaging schools: Fostering high school students' motivation to learn. Washington, DC: National Academy Press.

Neuville, S., Frenay, M., \& Bourgeois, E. (2007). Task value, self-efficacy and goal orientations: Impact on self-regulated learning, choice and performance among university students. Psychologica Belgica, 47(1-2), 95-117. http://dx.doi.org/10.5334/pb-47-1-95

Newmann, F. M., Wehlage, G. G., \& Lamborn, S. D. (1992). The significance and sources of student engagement. In F. M. Newmann (Ed.), Student engagement and achievement in American secondary schools (pp.11-39). New York: Teachers College Press.

Ouweneel, E., Le Blanc, P. M., \& Schaufeli, W. B. (2011). Flourishing students: A longitudinal study on positive emotions, personal resources, and study engagement. The Journal of Positive Psychology, 6(2), 142-153. http://dx.doi.org/10.1080/17439760.2011.558847

Ouweneel, E., Le Blanc, P. M., \& Schaufeli, W. B. (2014). On being grateful and kind: Results of two randomized controlled trials on study-related emotions and academic engagement. The Journal of Psychology: Interdisciplinary and Applied, 148(1), 37-60. http://dx.doi.org/10.1080/00223980.2012.742854

Ouweneel, E., Schaufeli, W. B., \& Le Blanc, P. M. (2013). Believe, and You Will Achieve: Changes over Time in Self - Efficacy, Engagement, and Performance. Applied Psychology: Health and Well-Being, 5(2), $225-247$. http://dx.doi.org/10.1111/aphw.12008

Patrick, H., Ryan, A. M., \& Kaplan, A. (2007). Early adolescents' perceptions of the classroom social environment, motivational beliefs, and engagement. Journal of Educational Psychology, 99(1), 83. http://dx.doi.org/10.1037/0022-0663.99.1.83

Perry, J. C., Liu, X., \& Pabian, Y. (2010). School engagement as a mediator of academic performance among urban youth: The role of career preparation, parental career support, and teacher support. The Counseling Psychologist, 38(2), 269-295. http://dx.doi.org/10.1177/0011000009349272

Phan, H. P. (2014a). An Integrated Framework Involving Enactive Learning Experiences, Mastery Goals, and Academic Engagement-Disengagement. Europe's Journal of Psychology, 10(1), 41-66. 
http://dx.doi.org/10.5964/ejop.v10i1.680

Phan, H. P. (2014b). Situating Psychological and Motivational Factors in Learning Contexts. Education, 4(3), 53-66. http://dx.doi.org/10.5923/j.edu.20140403.01

Phan, H. P. (2014c). Interrelations that foster learning: An investigation of two correlational studies. International Journal of Psychology. http://dx.doi.org/10.1002/ijop.12127

Phan, H. P., \& Ngu, B. H. (2014a). Longitudinal Examination of Personal Self-Efficacy and Engagement-Related Attributes: How Do they Relate. American Journal of Applied Psychology, 3(4), 80-91. http://dx.doi.org/10.11648/j.ajap.20140304.11

Phan, H. P., \& Ngu, B. H. (2014b). An Empirical Analysis of Students' Learning and Achievements: A Motivational Approach. Education Journal, 3(4), 203-216. http://dx.doi.org/10.11648/j.edu.20140304.11

Reeve, J., \& Lee, W. (2014). Students' classroom engagement produces longitudinal changes in classroom motivation. Journal of Educational Psychology, 106(2), 527-540. http://dx.doi.org/10.1037/a0034934

Reeve, J., \& Tseng, C.-M. (2011). Agency as a Fourth Aspect of Students' Engagement during Learning $\begin{array}{lllll}\text { Activities. } & \text { Contemporary } & \text { Educational } & \text { 257-267. }\end{array}$ http://dx.doi.org/10.1016/j.cedpsych.2011.05.002

Reschly, A. L., \& Christenson, S. L. (2006). Prediction of Dropout among Students with Mild Disabilities: A Case for the Inclusion of Student Engagement Variables. Remedial and Special Education, 27(5), 276-292. http://dx.doi.org/10.1177/07419325060270050301

Rumberger, R. (2004). Why students drop out of school. In G. Orfield (Ed.), Dropouts in America: Confronting the Graduation Rate Crisis (pp. 131-155). Cambridge, MA: Harvard Education Press.

Salanova, M., Schaufeli, W., Martínez, I., \& Bresó, E. (2010). How obstacles and facilitators predict academic performance: The mediating role of study burnout and engagement. Anxiety, Stress \& Coping, 23(1), 53-70. http://dx.doi.org/10.1080/10615800802609965

Salmela-Aro, K., \& Upadaya, K. (2012). The Schoolwork Engagement Inventory: Energy, dedication, and absorption (EDA). European Journal of Psychological Assessment, 28(1), 60. http://dx.doi.org/10.1027/1015-5759/a000091

Salmela-Aro, K., \& Upadyaya, K. (2014). School burnout and engagement in the context of demands-resources model. British Journal of Educational Psychology, 84(1), 137-151. http://dx.doi.org/10.1111/bjep.12018

Salmela-Aro, K., Tolvanen, A., \& Nurmi, J.-E. (2009). Achievement Strategies during University Studies Predict Early Career Burnout and Engagement. Journal of Vocational Behavior, 75(2), 162-172. http://dx.doi.org/10.1016/j.jvb.2009.03.009

Schaufeli, W. B., Salanova, M., González-romá, V., \& Bakker, A. B. (2002). The Measurement of Engagement and Burnout: A Two Sample Confirmatory Factor Analytic Approach. Journal of Happiness Studies, 3(1), 71-92. http://dx.doi.org/10.1023/A:1015630930326

Schunk, D. H. (1981). Modeling and attributional effects on children's achievement: A self-efficacy analysis. Journal of Educational Psychology, 73(1), 93. http://dx.doi.org/10.1037/0022-0663.73.1.93

Schunk, D. H. (1987). Peer Models and Children's Behavioral Change. Review of Educational Research, 57(2), 149-174. http://dx.doi.org/10.3102/00346543057002149

Schunk, D. H., \& Hanson, A. R. (1985). Peer models: Influence on children's self-efficacy and achievement. Journal of Educational Psychology, 77(3), 313-322. http://dx.doi.org/10.1037/0022-0663.77.3.313

Sharma, B. R., \& Bhaumik, P. K. (2013). Student engagement and its predictors: An exploratory study in an Indian business school. Global business review, 14(1(3)), 25-42. http://dx.doi.org/10.1177/0972150912466364

Sinatra, G. M., Heddy, B. C., \& Lombardi, D. (2015). The Challenges of Defining and Measuring Student $\begin{array}{lllll}\text { Engagement in } & \text { Science. }\end{array}$ http://dx.doi.org/10.1080/00461520.2014.1002924

Skinner, E. A., \& Belmont, M. J. (1993). Motivation in the classroom: Reciprocal effects of teacher behavior and student engagement across the school year. Journal of Educational Psychology, 85(4), 571-581. http://dx.doi.org/10.1037/0022-0663.85.4.571

Skinner, E. A., Kindermann, T. A., \& Furrer, C. J. (2009). A Motivational Perspective on Engagement and 
Disaffection: Conceptualization and Assessment of Children's Behavioral and Emotional Participation in Academic Activities in the Classroom. Educational and Psychological Measurement, 69(3), 493-525. http://dx.doi.org/10.1177/0013164408323233

Skinner, E. A., Wellborn, J. G., \& Connell, J. P. (1990). What it takes to do well in school and whether I've got it: A process model of perceived control and children's engagement and achievement in school. Journal of Educational Psychology, 82(1), 22-32. http://dx.doi.org/10.1037/0022-0663.82.1.22

Tuominen-Soini, H., \& Salmela-Aro, K. (2014). Schoolwork engagement and burnout among Finnish high school students and young adults: Profiles, progressions, and educational outcomes. Developmental Psychology, 50(3), 649. http://dx.doi.org/10.1037/a0033898

Upadyaya, K., \& Salmela-Aro, K. (2013). Development of school engagement in association with academic success and well-being in varying social contexts: A review of empirical research. European Psychologist, 18(2), 136-147. http://dx.doi.org/10.1027/1016-9040/a000143

Vasalampi, K., Salmela-Aro, K., \& Nurmi, J.-E. (2009). Adolescents' self-concordance, school engagement, and burnout predict their educational trajectories. European Psychologist, 14(4), 332-341. http://dx.doi.org/10.1027/1016-9040.14

Wang, M. T., \& Eccles, J. S. (2012a). Adolescent behavioral, emotional, and cognitive engagement trajectories in school and their differential relations to educational success. Journal of Research on Adolescence, 22(1), 31-39. http://dx.doi.org/10.1111/j.1532-7795.2011.00753.x

Wang, M. T., \& Eccles, J. S. (2012b). Social support matters: Longitudinal effects of social support on three dimensions of school engagement from middle to high school. Child Development, 83(3), 877-895. http://dx.doi.org/10.1111/j.1467-8624.2012.01745.x

Wang, M.-T., \& Eccles, J. S. (2013). School context, achievement motivation, and academic engagement: A longitudinal study of school engagement using a multidimensional perspective. Learning and Instruction, 28, 12-23. http://dx.doi.org/10.1016/j.learninstruc.2013.04.002

Wang, M.-T., \& Fredricks, J. A. (2014). The Reciprocal Links between School Engagement, Youth Problem Behaviors, and School Dropout during Adolescence. Child Development, 85(2), 722-737. http://dx.doi.org/10.1111/cdev.12138

Wang, M.-T., \& Holcombe, R. (2010). Adolescents' perceptions of school environment, engagement, and academic achievement in middle school. American Educational Research Journal, 47(3), 633-662. http://dx.doi.org/10.3102/0002831209361209

Wang, M.-T., Willett, J. B., \& Eccles, J. S. (2011). The Assessment of School Engagement: Examining Dimensionality and Measurement Invariance by Gender and Race/Ethnicity. Journal of School Psychology, 49(4), 465-480. http://dx.doi.org/10.1016/j.jsp.2011.04.001

Wehlage, G., Rutter, R., Smith, G., Lesko, N., \& Fernandez, R. (1989). Reducing the Risk: School as communities of support. Philadelphia: The Falmer Press.

Willms, J. D. (2003). Student engagement at school: A sense of belonging and participation; Results from PISA 2000. Retrieved from http://www.oecd.org/education/school/programmeforinternationalstudentassessmentpi sa/33689437.pdf

\section{Copyrights}

Copyright for this article is retained by the author(s), with first publication rights granted to the journal.

This is an open-access article distributed under the terms and conditions of the Creative Commons Attribution license (http://creativecommons.org/licenses/by/4.0/). 